ISSN 1014-4874

DOI : http://dx.doi.org/10.4314/ri.v26i1.6

\title{
Socio-Economic Impacts of Rain Water Harvesting Technologies in Rwanda: A case study of Nyaruguru District, Southern Province
}

Alfred R. Bizoza and Gloria Umutoni

\begin{abstract}
This study was carried out in Nyaruguru District, Southern Province of Rwanda. The aim is to assess the socio-economic impacts of Rain Water Harvesting (RWH) technologies established in the above research area. Results from the analysis postulate that there is not yet significant effects of already established Rain Water Harvesting Technologies on socio-economic conditions of sample households. However, the study reveals greater willingness of sample households for ownership and maintenance of established RWH technologies. Lack of economic capacity to materialize such willingness remains a challenge to be addressed by both the government and other development officials in the research area.
\end{abstract}

Key Words: Socio-economic impacts, Rain Water Harvesting, Nyaruguru District, Rwanda

\section{Introduction}

Water is globally known as capital product not only for consumption but also for agricultural production (Rokstrom et al, 2003). In Africa, most of agricultural farming systems are rain fed; crop and animal production depend heavily on natural precipitation. Although past attempts in promoting this farming system; the problem of food security and poverty remain unsolved in many undeveloped countries including Rwanda. In addition, rain fed technologies claimed to be technically sound, economically viable and resource neutral, have not been widely accepted by small scale farmers. Part of reasons is the un-suitability of proposed technologies and the prevailing social, economic, cultural milieu; and partly due to delivery systems of these technologies by development officials. (Jostein and Richard 1996).

Being aware of the above lacunae, among others, several nations and international institutions or agencies have developed new approaches for rural development including the rain water harvest facilities to complement 
the rain fed farming system through irrigation. In Rwanda, rain-fed farming system is dominant and the main source of water is rain. Yet, the country is facing major water related challenges. These include loss of runoff and inadequate storage facilities, inappropriate farming methods, inadequate skills and knowledge about Rain Water Harvesting (RWH), environmental degradation, low soil fertility, to name few. During rainy seasons, some parts of the country suffer from soil erosion caused by runoff of water; while in dry period other areas such as in the Eastern part of the country face serious problem of dryness which, affect residents in terms of food security.

Different efforts towards RWH in Rwanda have been undertaken mostly by the Ministry of Agriculture since 2007 to improve agricultural production towards food security. The RWH technologies introduced include plastic ponds and tanks for agricultural and domestic use. These technology options add to the existing traditional water harvesting methods used by farmers. Plastic ponds and tanks are expected to be more efficient in water harvesting which, in turn, is used for irrigation, feed the livestock, and household consumption. But their existence does not guaranty their adoption and fully use of them by farmers for multiple factors including high construction and maintenance costs that these enquire. For this reason, different extension strategies have been put in place by the Rwandan government and other development officials (e.g. RADA, JICA, NELSAP, CUEP) to sensitize the population on the necessity and the benefits of RWH facilities so as to raise their awareness and adoption of the proposed RWH facilities.

However, little is known about their socio-economic impacts since installed at household level. The aim of this study is to assess if the established RWH are being used by sample households and the extent to which they are beneficial at household level. Section 2 gives materials and methods of the study an overview of RWH methods used in Rwanda. Section 3 present the empirical results of this study ended with some conclusions and policy options.

\section{Materials and Methods}

\section{The Study area}

This study was mainly carried out in Cyahinda Sector of Nyaruguru District, Southern Province of Rwanda (See Figure 1). We also collected information in the neighbouring Sector of the same district to serve as the bench mark to assess the socio-economic impacts of established RWH facilities. Cyahinda is one of the intervention sites of CUEP project of 
FAO. Cyahinda Sector was purposely selected as the study area. A random sample of 102 households - 61 from treatment sector (Cyahinda) and 41 from the bench mark sector (Munini), provided information of this research. Cyahinda Sector accounts about 4208 households located in five cells. A stratified random sampling procedure was followed (Bizoza and De Graaff 2010) to obtain cells and villages covered by this study. The following Figure 1 shows the sites where the RWH facilities were established by the CUEP project in Nyaruguru District.

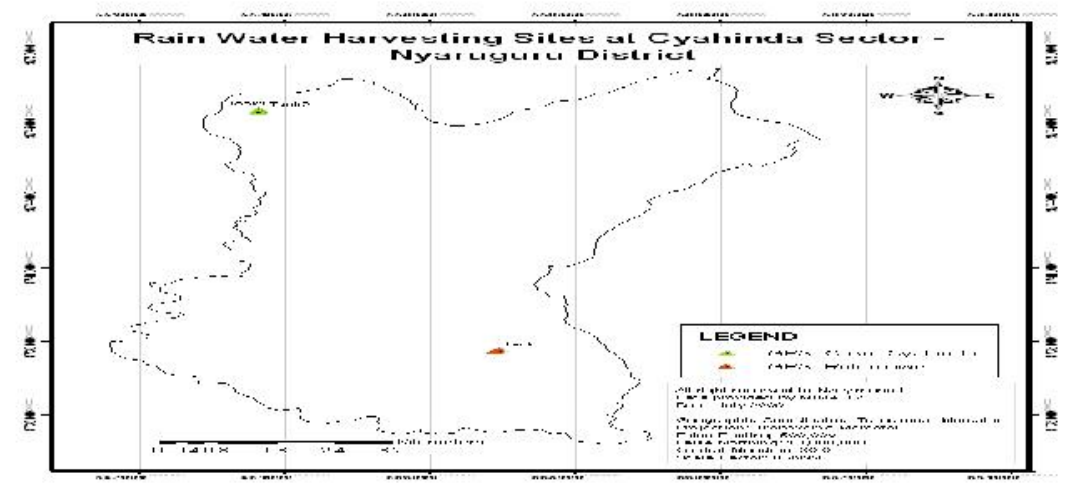

Figure1: RWH sites in Cyahinda Sector, Nyaruguru District Source: Copy right, Nzeyimana (2010).

\section{An overview of RWH methods used in Rwanda}

The two Figures (2.1 and 2.2. as bellow) represent the "underground tank 'and the plastic pond, respectively. The underground tank is constructed at Murama school and collects water from rooftops of the building of the same school. Therefore, rain water harvested using this tank is used to clean the class rooms and the sanitation facilities. The same rain water is also used for irrigation (spraying) on vegetable gardens in the adjacent areas. This underground tank has the capacity to contain about $60 \mathrm{~m}^{3}$. Its construction costs are estimated at 3 millions of Rwandan Francs (about 5 thousand US dollars @ a rate of 600 Frw/1 USD).

Contrary to the underground tank, the plastic pond (Figure 2.2.) serves purposely for agricultural production. This has been constructed in Rwamagana, Eastern province in 2008 for a cost of about 1.5 million Rwandan Francs and can contain $200 \mathrm{~m}^{3}$. This plastic pond collects runoff water to be used in irrigation of surrounding field by the intermediary of a machine which pumps water from the plastic pond to the perforated pipe. The pipes measure 50 meters and they cross the farm to easy the irrigation process. 


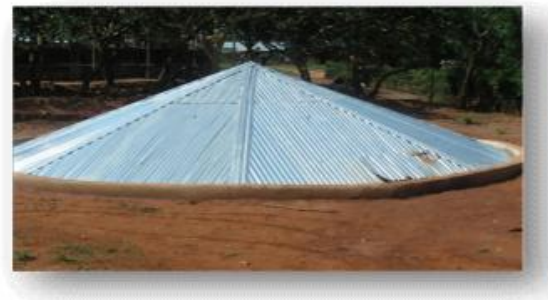

Figure 2.1. Underground tank

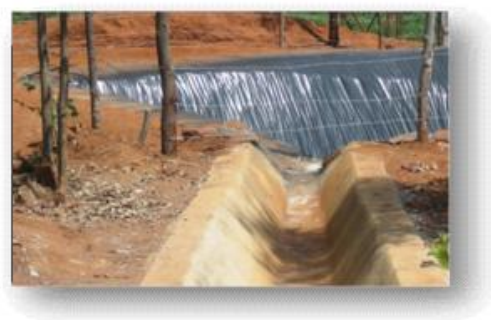

Figure 2.2. Plastic pond.

Source: CUEP, 2009

The following tank types are known as the 'Up ground tanks' ( see Figure 3 ). They are the most used in many parts of Rwanda.. Harvested rain water using these tanks is mainly used for domestic consumption. The capacity of this tank is about $20 \mathrm{~m}^{3}$. The unit cost of its construction is estimated at 2 million Rwandan Francs. This type, although sustainable, seems highly expensive and very few farmers or individual households can afford its establishment.

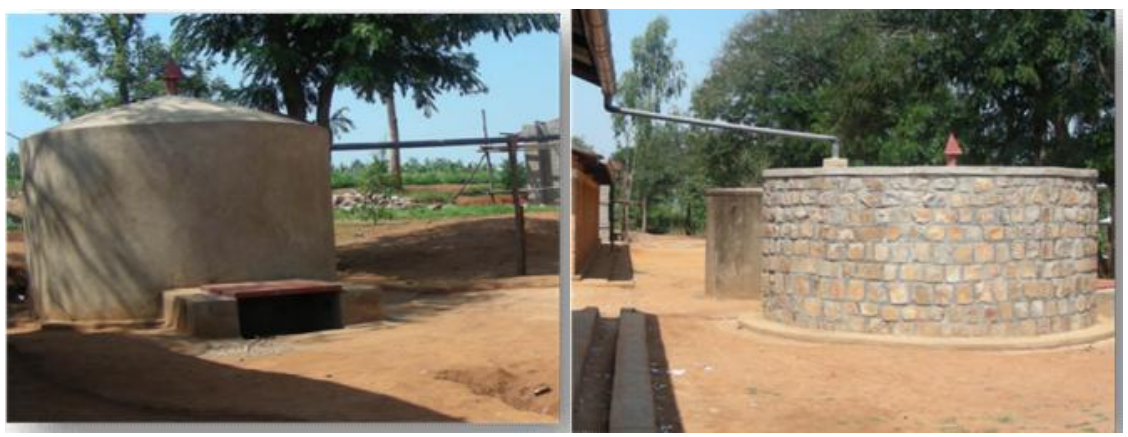

Figure 3.Up ground tank - Model 1 and 2 (Murama Primary School)

Source: CUEP, 2009

Traditional types of rain water harvesting include 'small house system'. These are constructed mainly for the livestock. A small house is constructed to receive water from neighbouring 'big' house. The unit cost for its construction is relatively small compared to the above (about 120 000 Frw or about 200 USD). These are found in Gicumbi District, Shagasha Sector. The picture 4.2 shows where extra water escape from the small house. 


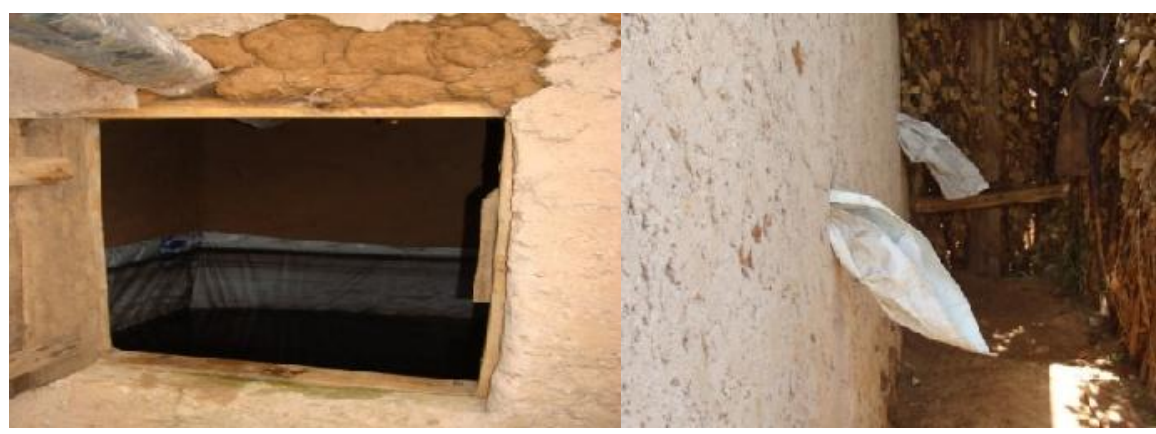

Figure 4.1 Small house to harvest water

Figure 4.2. Means to evacuate extra water

\section{Empirical Results}

\subsection{Socio-economic Characteristics of heads of households}

Table 1 bellow presents some of the socio-economic characteristics of 102 survey respondents. The overall average family size for the households from both sectors is estimated at 5 family members which is close to the family size at country level of 5.5 in 2007 (NISR, 2007). The average of 2.45 of the marital status implies that most of Households are headed and managed by both the husband and the woman. With respect to the gender, 68 percent of survey respondents are males. The average age of 44.14 shows that the study population is yet in the active age and this stands also for their respective activity experience. In terms of formal education, a scale of 0 to 4 was used to measure this variable ( 0 stands for illiteracy and 4 if attended the university). It is clear that the majority is within the category of 0 and 1 which stands for primary school (0.78). The main activity seems to be the agriculture as the average is around 1 which stands for the agriculture option compared to non-farm activities. The main reasons for not being involved in non-farm activities are that there are limited non-farm options in addition to lack of education. These characteristics helps to understand the drivers

Table 1: Socio-economic characteristics of the heads of households

\begin{tabular}{lllllll}
\hline Characteristics & \multicolumn{2}{c}{ Cyahinda $(\mathrm{N}=61)$} & \multicolumn{2}{l}{ Munini $(\mathrm{N}=41)$} & \multicolumn{2}{c}{ Study area(N=102) } \\
\cline { 2 - 7 } & Mean & Std. Dev & Mean & Std. Dev & Mean & Std. Dev \\
\hline Family size & 5.16 & 2.05 & 4.98 & 1.891 & 5.09 & 1.98 \\
Marital status & 2.45 & 0.84 & 2.24 & 0.97 & 2.36 & 0.89 \\
Gender & 0.72 & 0.45 & 0.61 & 0.49 & 0.68 & 0.47 \\
Age & 42.68 & 13.72 & 46.27 & 17.16 & 44.14 & 15.23 \\
Formal & 0.84 & 0.63 & 0.66 & 0.57 & 0.76 & 0.61 \\
education & 1.18 & 0.69 & 1.15 & 0.65 & 1.17 & 0.67 \\
Main activity & 0.03 & 0.18 & 0.02 & 0.15 & 0.03 & 0.170 \\
RWH training & 0 & & & & & \\
\hline
\end{tabular}




\section{Household assets}

The interest was also to know the assets owned by the sample households. It is evidenced from Table (2) that most of the households own their houses (87 per cent). For those with houses; their roofs are mainly made by tailors (83 percent). Apart from owning a house or being able to rent it; survey respondents confirmed that they do have other facilities that allow them for communication (radio), transport (bicycle), and electricity although a few number reported having access to it (1 percent).The total sample (100 percent) confirmed having a hoe that they use mainly for their land cultivation.

Table 21: Reported household assets and facilities

\begin{tabular}{lcccccc}
\hline HH assets & \multicolumn{2}{c}{ Cyahinda $(\mathrm{N}=61)$} & Munini $(\mathrm{N}=41)$ & \multicolumn{2}{c}{$\begin{array}{l}\text { Study area } \\
(\mathrm{N}=102)\end{array}$} \\
& Mean & Std. Dev. & Mean & Std. Dev. & Mean & Std. Dev \\
\hline Habitation & 1.18 & 0.53 & 1.27 & 0.67 & 1.22 & 0.591 \\
roof type & 2.02 & 0.38 & 1.88 & 0.51 & 1.96 & 0.44 \\
improved latrine & 0.66 & 0.51 & 0.76 & 0.43 & 0.70 & 0.48 \\
Electricity & 0.02 & 0.13 & 0.00 & 0.00 & 0.01 & 0.50 \\
Hoe & 1.00 & 0.00 & 1.00 & 0.00 & 1.00 & 0 \\
Radio & 0.66 & 0.48 & 0.68 & 0.47 & 0.67 & 0.47 \\
Bicycle & 0.07 & 0.25 & 0.05 & 0.22 & 0.06 & 0.23 \\
\hline
\end{tabular}

\section{Land use and tenure}

This study considers also land use and tenure as key determinants of the decision to invest in water harvesting techniques. Per capita farm size is estimated at 2.35 ha (including land for cultivation and for other uses like forest plantation). The average number of plots for land cultivation is also estimated at 2 plots per household. About 97 percent use their land for annual cropping compared to other land uses like grazing, perennial cropping (e.g. cassava) and tree plantation. In terms of land tenure, it was found that farmers can both have their own land or/ and rent. The average farm size rented is estimated at 0.14 ha. The average distance from home to the farm is between 1 to 30 minutes. 


\section{Crop production and Access to inputs in the research area}

With respect to agricultural production, the interest in this sub-section is to know major crops cultivated in the study area. Results reveal that beans and sweat potatoes are the most cultivated crop in the research area (97 per cent).The sorghum is also highly produced as 83 percent of the sample $\mathrm{HHH}$ confirm its production. Cassava represent 33 percent compared to Irish potatoes which is represented by 24 percent.

When farmers were asked if they do also produce vegetables; only 59 percent of the survey respondents cultivate vegetables. The latter is mostly cultivated in the kitchen garden (currently promoted under the Agasozi Ndatwa policy) and at the homestead. Normally, cultivating vegetables requires additional measures like irrigation. About 26 percent of survey respondents confirmed that they do practice the irrigation for improved production of vegetables (see Table 3).

Table 3: Cultivation of Vegetables

\begin{tabular}{lrrrrrrr}
\hline & \multicolumn{2}{c}{ Cyahinda } & \multicolumn{2}{c}{ Munini } & \multicolumn{2}{c}{ Study area } \\
\hline $\begin{array}{l}\text { Do you produce vegetables } \\
\text { at your homestead }\end{array}$ & Counts & Percent & Counts & Percent & Counts & Percent \\
\cline { 2 - 7 } No & 24 & 39.0 & 18 & 43.9 & 42 & 41.0 \\
Yes & 37 & 61.0 & 23 & 56.1 & 60 & 59.0 \\
Are they irrigated & 27 & 75.0 & 17 & 72.0 & 44 & 73.8 \\
No & 10 & 25.0 & 6 & 28.0 & 16 & 26.2 \\
Yes & & & & & & \\
\hline
\end{tabular}

It is well known that inputs are the most determinants of crop production. In this study, we considered some of the inputs required in crop production. The purpose here is to find out if they do have problem or ease to access inputs. It was revealed that farmers have an easy access to seeds (99 percent) and most of these seeds are obtained from the market (66 percent). Due to lack of sufficient liquidity, few farmers use inorganic fertilizers. About 67 percent of survey respondents confirmed for not using inorganic fertilizers. Only those sponsored by government or NGO subsidies use inorganic fertilizers and these are mostly applied for maize and wheat cultivation. Consequently, this constitutes a key constraint for crop production (as confirmed by 72 percent of the respondents) and hence reduced farm income. Drought as constraint for improved production was only maintained by 10 percent. It is suggested that mechanisms for enhanced access to inorganic fertilizers would improve the current level of production, among others. 


\section{Livestock}

Most of the time, in agricultural research, it is not easy to separate agricultural production to animal husbandry especially in the Rwandan context. One of the reasons is that manure from livestock is seen as part of key inputs used by farmers to increase agricultural production. The survey of this study revealed two categories of animal husbandry for cattle and goat namely breeding of own livestock and a breeding of someone's 'livestock commonly known as indagizo or inka ya kaguru. Descriptive statistics as presented in Table 8 show that around 37 percent of interviewed HHs in both sectors have at least one cow while 15 percent are breeding cows from neighbours to benefit animal manure and sometimes milk. About 22 per cent of survey respondents own at least one goat while 5 per cent bread goats from others. The percentage of heads of $\mathrm{HH}$ owning at least 1 pig or 1 rabbit is respectively 20 and 11 of the whole sample in both two sectors.

\section{Food security}

Food security, as a concept emerged at FAO's World Food conference in 1974, it has since been defined in several ways (Saad, 2000). The maiden meaning of the concept of food security was the availability of sufficient food supply at the global, regional and national level. However, since 1980 's it has been recognized that adequacy of food supply at the global or national levels does not guarantee access to food at community or $\mathrm{HH}$ levels (Maxwell and Smith 1992). Consequently, the focus and unit of analysis with regard to food security has recently shifted from the global and national to household and individual levels. That is why we included in our research questions regarding the food security at $\mathrm{HH}$ level. Table 9 summarizes some of descriptive results. About 60 percent of the sample buys legumes. Beans are bought by 38 percent and Irish potatoes is bought by 40per cent. Maize flower (Kawunga) and rice are equally bought (12per cent).Sweet potatoes and cassava are rarely bought as the percentage of interviewed $\mathrm{HH}$ in the study area buying them is respectively 5 and 6 per cent. The fruits mainly consumed by the sample households are: avocado (73 per cent), passion fruits ( 38 per cent), plums ( 25 per cent per cent $)$, guava (13per cent), orange (6per cent ) and banana (2per cent). Out of 102 households interviewed, most of them (79 percent) are able to have an average of 2 meals per day. However only 25 percent of sample households sustain that they are not able to meet the 3 meals which is the standard number of meals per day. 


\section{Health}

The impact of any technology or project is also evaluated based on its contribution with respect to its impacts on people including the health of beneficiaries. Given the importance of health in evaluating people's lives; we then decided to consider this aspect in this study. Major diseases reported by survey respondents include malaria and intestinal parasites (77 per cent). However, 91 percent of the sample HHHs are members of a health insurance scheme compared to 9 percent who reported not belonging to any health insurance scheme due to lack of required membership fees.

Table 4: Major illnesses in the study area and access to medical insurance

\begin{tabular}{lllllll}
\hline & \multicolumn{2}{l}{ Cyahinda } & \multicolumn{2}{c}{ Munini } & \multicolumn{2}{c}{ Study area } \\
\cline { 2 - 5 } Types of diseases & Mean & Std. Dev & Mean & Std. Dev & Mean & Std. Dev \\
\hline Malaria & 0.75 & 0.43 & 0.80 & 0.40 & 0.77 & 0.42 \\
intestinal parasite & 0.70 & 0.46 & 0.88 & 0.33 & 0.77 & 0.42 \\
Flue & 0.18 & 0.39 & 0.34 & 0.48 & 0.25 & 0.43 \\
water related illness & 0.34 & 0.51 & 0.51 & 0.55 & 0.41 & 0.53 \\
member of health insurance & 0.87 & 0.34 & 0.98 & 0.15 & 0.91 & 0.28 \\
if no insurance why & 1 & 0 & 1 & 0 & 1 & 0 \\
\hline
\end{tabular}

\subsection{Access to water at household level}

Water is indispensable for its wide range of usage. The principal source of water in the study area is drop pipes. Children are the ones who mainly fetch water and most of the sample spends between 10 to 30 minutes to reach the water source from their residences. The overall average quantity of water collected from rivers or other sources in dry season by the sample households is about 54 litters; while in rain season it is estimated at 31.73 litters/day. It is clear that, in dry season that is when households fetch more water from different sources. In contrast, in rain season, water used at household level is complemented by the rain harvests rom the roofs of their houses. This is a clear indication that the rain is an additional source of water needed at household level and reduce the cost of transportation from rivers to secure the quantity of water needed. 
Table 5: Estimates of water needs per day and per household

\begin{tabular}{|c|c|c|c|c|c|c|}
\hline \multirow[b]{2}{*}{ Questions asked } & \multicolumn{2}{|c|}{ Cyahinda } & \multicolumn{2}{|l|}{ Munini } & \multicolumn{2}{|c|}{ Study area } \\
\hline & Mean & Std. Dev & Mean & Std. Dev & Mean & Std. Dev \\
\hline Sources of water & 1.21 & 0.66 & 1.10 & 0.43 & 1.17 & 0.58 \\
\hline $\begin{array}{l}\text { Distance from home to } \\
\text { the source }\end{array}$ & 1.79 & 0.75 & 1.68 & 0.52 & 1.75 & 0.67 \\
\hline Who collects water & 1.84 & 0.61 & 1.63 & 0.49 & 1.75 & 0.57 \\
\hline $\begin{array}{l}\text { Average quantity of } \\
\text { water collected in dry } \\
\text { season }\end{array}$ & 53.02 & 27.90 & 54.56 & 29.86 & 53.64 & 28.57 \\
\hline $\begin{array}{l}\text { average quantity of } \\
\text { water collected in rain } \\
\text { season }\end{array}$ & 32.85 & 17.28 & 30.05 & 17.63 & 31.73 & 17.39 \\
\hline $\begin{array}{l}\text { Average quantity of } \\
\text { water used in dry } \\
\text { season }\end{array}$ & 49.49 & 28.51 & 50.66 & 27.62 & 49.96 & 28.02 \\
\hline $\begin{array}{l}\text { Average quantity of } \\
\text { water used in rain } \\
\text { season }\end{array}$ & 27.59 & 18.23 & 28.49 & 24.84 & 27.95 & 21.02 \\
\hline $\begin{array}{l}\text { Average quantity of } \\
\text { water needed in dry } \\
\text { season }\end{array}$ & 89.67 & 41.32 & 85.05 & 33.73 & 87.81 & 38.34 \\
\hline $\begin{array}{l}\text { Average quantity of } \\
\text { water needed in rain } \\
\text { season }\end{array}$ & 60.90 & 25.45 & 62.98 & 44.42 & 61.74 & 34.19 \\
\hline
\end{tabular}

About more or less 50 litters on average are the estimate of water used per day per household in dry season compared to 28 litters in rain season out of what is collected. It was not easy to estimate water harvested. But, from the above calculations, the difference can represent what they gain from the rain that is about 22 litters per day per household during rainy season. Yet, farmer estimates show that the estimated average quantity of water needed per day per household is 87.81 litters during dry seasons compared to 61.74 in rain seasons. The difference could be explained by the needs of water which is higher in dry season than in rain season for different reasons such as, irrigation, more production of banana beer and also more need of drinking water as well as laundry.

\subsection{Awareness of RWH techniques and Environmental protection}

The interest in this study was also to know the extent to which survey respondents are aware of RWH techniques. The evidence is that respondents are aware of these techniques but few implement them- only 1 
per cent has established these techniques in their homestead or farms. For those with RWH infrastructures, their main motivation is to control soil erosion and environmental protection. This is supported by 1 per cent of the survey respondents. But, very few respondents maintain that established RWH techniques are made to allow further access to water for both home consumption and irrigation. In addition, respondents confirmed that there is moderate soil erosion. Reason why some of SWC techniques were also reported as part of water control measures. These include bench terraces, trenches and hedge rows (Bizoza and De Graaff, 2010).

Table 6: Awareness of RWH techniques

\begin{tabular}{lllllll}
\hline Environment & \multicolumn{2}{c}{ Cyahinda } & \multicolumn{2}{c}{ Munini } & \multicolumn{2}{c}{ Study area } \\
\cline { 2 - 7 } & Mean & Std. Dev. & Mean & Std. Dev & Mean & Std. Dev \\
\hline RWH in HH & 0.02 & 0.12 & 0 & 0 & 0.01 & 0.10 \\
Reason for RWH & $\mathbf{2 . 2 5}$ & 1.69 & 2.88 & 2.19 & 2.50 & 1.92 \\
Erosion in the area & 1.70 & 1.40 & 1.80 & 1.34 & 1.75 & 1.37 \\
Terraces & 0.03 & 0.18 & 0.05 & 0.22 & 0.04 & 0.19 \\
Trenches & 0.67 & 0.47 & 0.49 & 0.50 & 0.60 & 0.49 \\
hedges rows & 0.97 & 0.18 & 0.85 & 0.36 & 0.92 & 0.27 \\
RWH in Fields & 0 & 0 & 0 & 0 & 0 & 0 \\
\hline
\end{tabular}

General observation in the field and in the data obtained from our sample respondents is that traditional or indigenous RWH techniques are yet dominant in the study area and elsewhere in Rwanda. Respondents sustain that harvested water is mainly used for laundry ( 93 per cent) and in toilette cleaning ( 89 per cent). About 41 percent of the sample harvest rain water for cattle breeding purposes while 34per cent use the water harvested for outside use (including irrigation of crops in the homestead). To complement the above discussion, some informal discussions were also made with some heads of schools where the RWH techniques are established. From their testimonies, we realized that the establishment of RWH infrastructures has reduced the distance from students going to fetch water. 
Table 7: Use of harvested rain water

\begin{tabular}{|c|c|c|c|c|c|c|}
\hline \multirow{2}{*}{$\begin{array}{l}\text { Uses of } \\
\text { harvested } \\
\text { water }\end{array}$} & \multicolumn{2}{|c|}{ Cyahinda } & \multicolumn{2}{|l|}{ Munini } & \multicolumn{2}{|c|}{ Study area } \\
\hline & Mean & Std. Dev & Mean & Std. Dev & Mean & Std. Dev \\
\hline Drinking & 0.3 & 0.180 & 0.05 & 0.218 & 0.04 & 0.195 \\
\hline outside use & 0.26 & 0.444 & 0.46 & 0.505 & 0.34 & 0.477 \\
\hline Laundry & 0.90 & 0.300 & 0.98 & 0.156 & 0.93 & 0.254 \\
\hline $\begin{array}{l}\text { Toilet } \\
\text { cleaning }\end{array}$ & 0.97 & 0.180 & 0.78 & 0.419 & 0.89 & 0.312 \\
\hline Cooking & 0.10 & 0.300 & 0.05 & 0.218 & 0.08 & 0.270 \\
\hline Feed Cattle & 0.47 & 0.503 & 0.32 & 0.471 & 0.41 & 0.494 \\
\hline
\end{tabular}

\section{Conclusions and Policy actions}

The main objective of this article was to assess the socio-economic impacts of RWH technologies in Nyaruguru District, Southern Rwanda. Results from the analysis postulate that there is not yet significant effects of already established Rain Water Harvesting Technologies on socio-economic conditions of sample households. However, the study reveals greater willingness of sample households for ownership and maintenance of established RWH technologies. Lack of economic capacity to materialize such willingness remains a challenge to be addressed by both the government and other development officials. Furthermore, based on the information obtained from survey respondents and from our personal observation when in the field; we argue that RHW for domestic use is the most needed and applied in the study area rather than for irrigation purposes. The reason could be that there is less drought and hence rely more on rain fed agriculture.

This study ends with some recommendations for policy actions. We recommend projects (.e.g) to assure the safety of the water harvested by the existing facilities in the study area. After noticing that RWH for domestic purposes is the most needed in the study area, and livestock farming is being promoted in the area, we recommend RWH interventions to try on the small house system (as indicated in Chapter 1 ) as it seems to be affordable by the majority of the sample population. Finally, given that this study was carried out at a small scale; a broader analysis is required to provide more knowledge and insights with respect to economics of rainwater harvesting in Rwanda. 


\section{Acknowledgments}

The authors thank the survey respondents for their time spent in responding to the survey. We do highly acknowledge the financial support for field data collection from FAO, Rwanda. We appreciate also the anonymous reviewer(s) for the comments on earlier draft of this paper.

\section{References}

1. Bizoza A.R. and De Graaff, J. (2010). Finacial Cost -Benefit Analysis of Bench Terraces in Rwanda. Journal of Land Degradation \& Development: In Press.

2. Clay. D, Reardon,T., Kangasniemi, J. 1998. Sustainable Intensification in the Highland Tropics: Rwandan farmers' investment in land conservation and soil fertility. Journal of Economic Development and Cultural Change, Vol. 46 (2): 351-377., University of Michigan State, USA. .

3. Jostein, L. and Richard, P., 1996. Extension strategy for resource-poor farmers in rainfed agriculture. Rajiv Beri: V.N.Rao at Macmillan India Press.

4. Maxwell, S. and Smith, M., 1992. "Household Food Security: A Conceptual Review," in S. Maxwell and T. Frankenberger (Des) Household food Security: Concepts, Indicators, and Measurements: A Technical Review. New York and Rome. UNICEF and IFAD.

5. Rokstroom, J., Barron, J. and Fox, P (2003). Water productivity in RainFed Agriculture: Challenges and opportunities for smallholder Farmers in Drought- prone tropical Agro ecosystem. In Kjne.J, Barker, R. and Molden D (Eds): Water productivity in Agriculture; Limits and opportunities for improvement. CAB International Publisher.

6. Saad, M.B., 2000. Food security for the food-insecure: New challenges and renewed commitments. Commissions for Sustainable Development (CSD). University College Dublin, Ireland. Position Paper for CSD-8, 2000. 